\title{
Growth Parameters of Onion (Allium cepa L. var. Cepa) as Affected by Nitrogen Fertilizer Rates and Intra-row Spacing Under Irrigation in Gode, South-Eastern Ethiopia
}

\author{
Weldemariam Seifu Gessesew ${ }^{1, *}$, Kebede Woldetsadik ${ }^{2}$, Wassu Mohammed ${ }^{2}$ \\ ${ }^{1}$ Department of Horticulture, College of Veterinary Medicine and Agriculture, Addis Ababa Univesity, Fiche, Ethiopia \\ ${ }^{2}$ Department of Plant Sciences, Haramaya University, Dire-Dawa, Ethiopia
}

Email address:

whamlove@gmail.com (W. S. Gessesew)

To cite this article:

Weldemariam Seifu Gessesew, Kebede Woldetsadik, Wassu Mohammed. Growth Parameters of Onion (Allium cepa L. var. Cepa) as Affected by Nitrogen Fertilizer Rates and Intra-row Spacing Under Irrigation in Gode, South-Eastern Ethiopia. Agriculture, Forestry and Fisheries. Vol. 4, No. 6, 2015, pp. 239-245. doi: 10.11648/j.aff.20150406.11

\begin{abstract}
The productivity of onion crop is low due to poor agronomic and management practices in Gode district. Therefore, a field experiment was conducted at Gode Polytechnic College demonstration farm in 2013 under irrigation to assess the effect of $\mathrm{N}$ fertilizer rates and intra-row spacing on growth parameters of onion (Allium cepa L.). The treatments were consisting of six rates of $\mathrm{N}$ fertilizer $\left(0,46,69,92,115,138 \mathrm{~kg} \mathrm{ha}^{-1}\right)$ and four levels of intra-row spacing $(7.5,10,12.5$ and $15 \mathrm{~cm})$ and the experiment was designed in RCBD with three replications. Results of the analysis revealed that the interaction effects of $\mathrm{N}$ rates and intra-row spacing showed highly significant $(\mathrm{P}<0.01)$ effect on leaf number. Plant maturity was delayed at higher $\mathrm{N}$ rates and wider intra-row spacings and vice-versa. The longest plant height was obtained from $15 \mathrm{~cm}$ intra-row spacing and $138 \mathrm{~kg} \mathrm{~N}$ $\mathrm{ha}^{-1}$ where as the shortest was recorded from $7.5 \mathrm{~cm}$ intra-row spacing without $\mathrm{N}$ fertilizer application. Longest leaf length was obtained from plants spaced at $15 \mathrm{~cm}$ fertilized with $138 \mathrm{~kg} \mathrm{~N} \mathrm{ha}^{-1}$. However, the shortest was recorded for plants grown in $7.5 \mathrm{~cm}$ intra-row spacings without $\mathrm{N}$ fertilizer. The overall result analysis showed thatgood growth performance of onion was obtained from $15 \mathrm{~cm}$ intra-row spacing combined with $138 \mathrm{~kg} \mathrm{~N}^{-1}$ fertilizer applications.
\end{abstract}

Keywords: Growth, Intra-row, Nitrogen, Parameters, Rates, Spacing

\section{Introduction}

Onion (Allium cepa L.) is an important underground vegetable bulb crop of tropical and subtropical part of the world [1]. It belongs to the genus Allium of the family Alleacea, which is originated in southwest Asia and the Mediterranean regions. Onion is one of the oldest cultivated vegetables which traced back to at least 5000 years and has been in cultivation for more than 4000 years. Onion as food, medicine and religious object was known during the first Egyptian dynasty in 3200 B.C. Onion, which is different from the other edible species of Alliums for its single bulb, is one of the most important bulb crops cultivated commercially in most parts of the world. It is usually propagated by true botanical seed [2, 3].

Ethiopia has a great potential to produce onion throughout the year both for local consumption and export. It is grown primarily for its bulb which is used for flavoring the local stew, 'wet' which is considerably important in the daily diet, mostly used as seasonings or as vegetables in stews. It is one of the richest sources of flavonoid in the human diet and flavonoid consumption has been associated with a reduced risk of cancer, heart disease and diabetes. In addition it is known for anti bacterial, antiviral, anti-allergenic and anti-inflammatory potential [4].

Onions (Allium cepa L.) as bulb onion and/or shallot is probably cultivated in all countries of tropical Africa including Ethiopia [5]. Onion requires adequate soil moisture due to the relatively short and small root system. Onions are sensitive to photoperiod. Long days are favorable to onion production as this enhances leaf development and formation which, in turn, is directly related to bulb size. Early varieties require 13 hours for bulb initiation while late varieties require 16 hours for bulb initiation. In Ethiopia onion can grow between 500 and 2400 meter above sea level, but the best growing altitude so far known is between 700and 1800 meter above sea level [6]. Thus, Onions are spread throughout the 
country being cultivated under both irrigated as well as rain fed conditions in different agro-climatic regions [7].

Onion is considered as one of the most important vegetable crops produced on large scale in Ethiopia. It also occupies economically important place among vegetables in the country. The area under onion is increasing from time to time mainly due to its high profitability per unit area and ease of production, and the increases in small scale irrigation areas. The crop is produced both under rain fed in the 'meher'season and under irrigation in the off season. In many areas of the country, the off season crop (under irrigation) constitutes much of the area under onion production. Despite the increase in cultivated areas, the productivity of onion is much lower than other African countries and the world average. The low productivity could be attributed to the limited availability of quality seeds and associated production technologies used [8]. According to [9] for private farmers' holdings in 'meher' season 2012/2013, the total area coverage by onion crop in the country was $21,865.4$ ha, with total production of $219,188.6 \mathrm{t}$ with average productivity of $10.02 \mathrm{t} \mathrm{ha}^{-1}$. This is very low yield compared to the world average of $19.7 \mathrm{t} \mathrm{ha}^{-1}[10]$ due to low soil fertility, salinity effect and inappropriate cultural practice [11].

The use of appropriate agronomic management has an undoubted contribution in increasing crop yield. One of the important measures to be taken in increasing the productivity of onion is to determine the optimum amount of fertilizers rates and spacing in each agro-ecology. Among the fertilizers, nitrogen containing ones is the most important, since it is being a component of amino acids and chlorophyll, promotes rapid vegetative growth, protein content and yield of the crop. According to author [12], it is very difficult to give general recommendation for onion that can be applicable to different agro ecological zones of the country. Another author [13] reported also to optimize onion productivity; full package of information is required for each growing region of the country.

The Shebelle river basin along the Gode district is one of the most suitable areas for the production of onion. Recently onion growers in the study area started producing onion for home consumption as well as cash crop by irrigation. Farmers in the study area are mostly engaged in livestock production and few have recently started sedentary agriculture. Thus, productivity of most of the crops, including onion, is low due to poor agronomic and management practices. Moreover, lack of improved varieties and seed, absence of recommended nitrogen fertilizer rate and plant spacing are the pertinent problems of the study area. Currently the nationally recommended fertilizer rate of $100 \mathrm{~kg}$ DAP ha ${ }^{-1}\left(46 \mathrm{kgP}_{2} \mathrm{O}_{5}\right.$ $\mathrm{ha}^{-1}$ ) and split application of $150 \mathrm{~kg}$ Urea ha ${ }^{-1}[14]$ are used along with $10 \mathrm{~cm}$ plant spacing [8] for onion production with no consideration of soil types. However, farmers in Gode area have no experience of applying the nationally recommended fertilizer rate and plant spacing rather they randomly practice undetermined fertilizer rate and plant spacing. In view of these, the present study was initiated to find out optimum and economic rates of fertilizer and intra-row spacing of onion crop for Gode province and the study was conducted with the objective of determining the effect of nitrogen fertilizer rates and intra-row spacing on onion growth parameters.

\section{Materials and Methods}

\subsection{Description of the Study Area}

A field experiment was conducted in 2013 from January to June under irrigation at Gode Polytechnic College Demonstration farm in Somali National Regional State, South-eastern Ethiopia. The site is situated at latitude of $5^{\circ} 57^{\prime}$ $\mathrm{N}$ and longitude of $43^{\circ} 27^{\prime} \mathrm{E}$. The experimental site lies at an altitude of about 300 m.a.s.l. It is characterized by high temperature, erratic rainfall, and sandy clay loam soil texture. Gode district has a vast area of plain suitable for large scale irrigated agriculture and livestock production. The study site is typified as arid to semi-arid climatic zone with mean maximum and minimum annual temperatures of 35 and $23.6^{\circ} \mathrm{C}$ respectively. The rainfall has a bi-modal distribution pattern with mean annual precipitation ranging from 150 to $340 \mathrm{~mm}$ which is not sufficient for rain fed production [15].

\subsection{Description of the Experimental Materials}

Onion cultivar called Seiyunn - Hadhramout - R.Y (Yemen $\mathrm{F}_{1}$ hybrid seed), locally named as Qalafo onion, was used as a test crop for the experiment. It is well adapted and widely cultivated in the study area and also has light red color, globe shaped bulb with pungent smell and can mature in 115-130 days. Its yield potential is 35-46 $\mathrm{t} \mathrm{ha}^{-1}$ (personal communication April, 2013). Urea $(46 \% \mathrm{~N})$ fertilizer was used as a source of nitrogen for the experiment. The national recommended rate of nitrogen fertilizer which was found adequate for dry bulb production in upper awash region was $92 \mathrm{~kg} \mathrm{~N} \mathrm{ha}^{-1}$ and $10 \mathrm{~cm}$ plant spacing was investigated at Melkassa and Were Research centers [8] and they were used as the basis to set the $\mathrm{N}$ fertilizer rates and intra- row spacing in this study.

\subsection{Treatments and Experimental Design}

The treatments consists of factorial combination of six rates of $\mathrm{N}$ fertilizer $\left(0,46,69,92,115\right.$ and $\left.138 \mathrm{~kg} \mathrm{ha}^{-1} \mathrm{~N}\right)$ and four levels of intra-row spacing $(7.5,10,12.5$, and $15 \mathrm{~cm})$. There were a total of 24 treatment combinations. The experiment was laid out in randomized complete block design (RCBD) with three replications. The size of each plot was $2 \times 3 \mathrm{~m}^{2}$ accommodating ten rows (five double rows planted on shoulders of $40 \mathrm{~cm}$ bed including furrow wide ridges) with 40 , 30,24 and 20 plants per row for the intra-row spacing of 7.5, $10,12.5$ and $15 \mathrm{~cm}$, respectively. The recommended inter-row spacing of $40 \mathrm{~cm}$ was maintained for all plots. The distance between plots and blocks were $1 \mathrm{~m}$ and $1.5 \mathrm{~m}$, respectively. The outer single rows at both sides of the plot and one plant at both ends of the rows were considered as border plants.

\subsection{Experimental Procedure}

Seedlings were raised on three sunken nursery beds with 
size of $1.2 \times 5 \mathrm{~m}^{2}$ from Yemen produced seed of locally named Qalafo onion. Seeds were obtained from shop of vegetable seed supplier and were sawn on January 01, 2013 at $10 \mathrm{~cm}$ distance between rows, lightly covered with soil and mulched with grass until seedlings are emerged $(2-5 \mathrm{~cm}$ from the soil). Seedlings were managed under nursery for six weeks and then after transplanted to the experimental plots.

Before transplanting seedlings, the experimental field was ploughed and harrowed by tractor. Large clods were broken down in order to make the land fine tilth, and then a total of 72 plots each with size of $2 \times 3 \mathrm{~m}^{2}$ were prepared in which 24 plots were allocated to each replication. Plots were leveled and furrows and ridges were prepared. The nursery beds were supplied with $100 \mathrm{~g}$ Urea $1.2 \times 5 \mathrm{~m}^{-2}$ [14]. Then seedlings were transplanted when they reached $12-15 \mathrm{~cm}$ height or 3-4 true leaves stage by carefully uprooting from nursery bed. One day before transplanting of seedlings, the nursery was irrigated for safe uplifting of seedlings. During transplanting only healthy, vigorous and uniform seedlings grown at the center of seedbeds were transplanted and gap filling was done within a week after transplanting.

The experiment was conducted under furrow irrigation method. Four day irrigation interval was maintained for the $1^{\text {st }}$ four weeks and then extended to seven days interval until 15 days to harvest, when irrigation was stopped completely. All other agronomic practices were applied as per the recommendation made for the crop for all plots throughout the experimental period. Harvesting of onion bulbs was done when $70 \%$ plants in each plot show neck fall. Harvested onion bulbs were cured for four days by windrowing on the ground before topping [14].

\subsection{Soil Sampling}

Soil sampling was done before transplanting of seedlings from five entire representative points of the experimental site from depth of $0-30 \mathrm{~cm}$ then mixed to form composite sample. This composite sample was sub-divided in to working samples for analysis and soil analysis for specific parameters was carried out at Addis Ababa city government environmental protection authority and water works design and supervision enterprise soil laboratories. The composite pre-planting soil samples were analyzed for soil $\mathrm{EC}$ and $\mathrm{pH}$ at 1:2.5 soils to water ratio using a glass electrode attached to $\mathrm{pH}$ digital meter, organic matter was determined by using [16], total $\mathrm{N}$ was determined using Kjeldhal method as described by [17], available $\mathrm{P}$ was determined by the methods of [18], exchangeable potassium and sodium determined by potentiometericaly with $1 \mathrm{M}$ ammonium acetate at $\mathrm{pH} 7.0$, Soil cation exchange capacity (CEC) was determined by ammonium acetate method [19] and Soil texture was determined by Bouyocous hydrometer method [20].

\subsection{Data Collection}

Growth components of onion were collected from 10 randomly selected and pre-tagged plants from the six central rows of each plot. Data were collected as per the procedures mentioned as follows.

Days to maturity: was recorded as the actual number of days from the date of transplanting to the time when $70 \%$ of plants in each plot showed neck fall [14].

Plant height $(\mathrm{cm})$ : was measured in centimeters from the soil surface to the tip of matured leaf in the plant at maturity using a ruler.

Leaf number per plant: was determined by counting the total number of leaves produced by sampled plants and the mean leaf numbers per plant was obtained by calculating the average number of leaves.

Leaf length $(\mathrm{cm})$ : was recorded as the average leaf length of the longest leaves of sampled plants at maturity.

\subsection{Data Analysis}

The data were subjected to analysis of variance (ANOVA) using SAS version 9.1 GLM procedures and least significant difference (LSD) was used to separate means at $p<0.05$ probability levels of significance.

\section{Results and Discussion}

\subsection{Selected Soil Physico-Chemical Properties of the Study Area}

Table 1. Soil physico-chemical properties of the experimental site before planting.

\begin{tabular}{lll}
\hline Soil properties & Results & Remark \\
\hline $\begin{array}{l}\text { Soil depth }(\mathrm{cm}) \\
\text { Particle size distribution (\%) }\end{array}$ & $0-30$ & \\
Clay (\%) & & \\
Silt (\%) & 23.08 & \\
Sand (\%) & 25.84 & \\
Soil textural class & 51.08 & \\
Bulk density (g/cm $\left.{ }^{3}\right)$ & & Sandy clay loam \\
Organic carbon (\%) & 1.08 & Satisfactory/ moderate \\
Organic matter content (\%) & 0.40 & Low \\
Total Nitrogen (\%) & 0.70 & Low \\
Available Phosphorus (ppm) & 0.02 & Very Low \\
CEC (c.mol/kg soil) & 29.34 & High \\
Exchangeable Sodium c.mol kg ${ }^{-1}$ & 14.6 & Moderate \\
EC $\left(\mathrm{dS} \mathrm{m} \mathrm{m}^{-1}\right)$ & 0.70 & Moderate \\
Soil $\mathrm{pH}$ & 0.729 & slightly saline \\
\hline
\end{tabular}

Source: Addis Ababa city government environmental protection authority and water works design and supervision enterprise soil laboratories.

The results of the laboratory analysis of some selected physio-chemical properties of the soil of experimental site are presented below (Table 1). Results of the soil analysis before planting showed that the soil of the site is sandy clay loam in texture with alkaline $(\mathrm{pH} 8.3)$ reaction. The soil had a bulk density of $1.08 \mathrm{~g} \mathrm{~cm}^{-3}$, and $0.02 \%, 29.34 \mathrm{ppm}, 0.70 \%$ of total $\mathrm{N}$, available phosphorous and, organic matter content, respectively. It had also $0.40 \%, 14.6 \mathrm{c} . \mathrm{mol} \mathrm{kg}^{-1}$ soil, $0.729 \mathrm{dS}$ $\mathrm{m}^{-1}$ and0.70 c.mol kg${ }^{-1}$ of organic carbon, CEC, EC, and exchangeable Sodium respectively. The rating under remark 
was done according to [21] and [22] suggestions.

According to the limit suggested by [16], the organic carbon $(1.43 \%)$ or organic matter content $(2.46 \%)$ of the soil was rated as very low before planting. According to the rating suggested by [23], the $\mathrm{N}$ content $(0.15 \%)$ before planting was rated as low. According to the rating suggested by [24], the phosphorus content (15.5 ppm) before planting was rated as medium. The $\operatorname{CEC}(39,13)$ before planting was rated as high as per the rating suggested by [23].

\subsection{Days to Maturity}

Days to maturity was significantly $(\mathrm{P}<0.05)$ affected by the main effect of fertilizer and intra-row spacing. However, fertilizer rates and intra-row spacing did not interact to influence days to maturity significantly. Days tomaturity of Qalafo onion variety was between 101 and 117 days.

Regardless of the intra-row spacing, days to maturity was prolonged in plants supplied with nitrogen levels, which were in statistical parity, as compared to plants which did not receive fertilizer. The highest $\mathrm{N}$ rate $\left(138 \mathrm{~kg} \mathrm{ha}^{-1}\right)$ delayed maturity of plants while plants which did not receive nitrogen fertilizer had early maturity. Plants supplied with 46, $69,92,115$ and $138 \mathrm{~kg} \mathrm{~N} \mathrm{ha}^{-1}$ extended days to maturity by about $2.61,3.52,8.02,9.58$ and $15.56 \%$, respectively; as compared to the plants in the control plot (Table 2).

The delay maturity due to $\mathrm{N}$ fertilizer application is attributed to the prolonged canopy growth in response to nitrogen rate which maintain physiological activity for an extended period and thereby continuing photosynthesis $[25,26]$. Similar results were reported by [27] on days to maturity onion which was prolonged in response to increased levels of farmyard manure (FYM) and N. According to author [28], $\mathrm{N}$ rate above $100 \mathrm{~kg} \mathrm{ha}^{-1}$ delayed maturity. Author [29] also observed that the $\mathrm{N}$ at the rate of $150 \mathrm{~kg} \mathrm{ha}^{-1}$ recorded the highest number of days to reach bulb maturity. The result is also in line with the finding of [30] who reported that application of $180 \mathrm{~kg} \mathrm{ha}^{-1} \mathrm{~N}$ prolonged the growing period of onion.

Irrespective of $\mathrm{N}$ fertilizer rates, closer plant spacing of $7.5 \mathrm{~cm}$ and $10 \mathrm{~cm}$ hastened by about 5 and 4 days, respectively, while wider plant spacing of 12.5 and $15 \mathrm{~cm}$ showed slightly delayed maturity (Table 2). This might be attributed to competition for light and nutrient in closer spacing, causing early bulb maturity while wider spacing allowed plants to have access for more nitrogen which prolonged maturity. Maturity was shortened from 134 to 124 days as reported by [31] when seeding rate increased from 100,000 to 200,000 per acre. The result is in agreement with the findings of $[32,25]$ who noted that bulb maturity is advanced by higher density planting, which is associated with a high leaf area index and hence light interception by the leaf canopy that advance the date of bulb scale initiation.

\subsection{Plant Height, Leaf Length and Leaf Number}

Plant height and leaf length were significantly $(\mathrm{P}<0.01)$ influenced by the main effect of intra-row spacing and $\mathrm{N}$ rates but not by the interaction of the two. However, leaf number was significantly $(\mathrm{P}<0.01)$ affected by intra-row spacing and $\mathrm{N}$ rates and their interaction effect $(\mathrm{P}<0.05)$.

\subsubsection{Plant Height}

Considering the independent effect of $\mathrm{N}$ rates alone, the longest plants were obtained when $\mathrm{N}$ was supplied at the rate of $138 \mathrm{~kg} \mathrm{ha}^{-1}$ and the shortest plants were observed in the control plot. The increase of plant height was 2.2, 4.4, 8.6, 13.17 and $25.17 \%$ as the increased $\mathrm{N}$ fertilizer rates of 46,69 , 92,115 and $138 \mathrm{~kg} \mathrm{ha}^{-1} \mathrm{~N}$, respectively, over the control (Table 2). This is because of the fact that $\mathrm{N}$ is mainly concerned with the vegetative growth of plants through cell division and elongation $[33,26]$. The result is in line with the research finding of [27] conducted at Gode who reported as increasing the rate of $\mathrm{N}$ supply from $0 \mathrm{~kg} \mathrm{ha}^{-1}$ to $100 \mathrm{~kg} \mathrm{ha}^{-1}$ significantly increased plant height by about $8 \%$. This result is consistent also with the findings of $[34,35]$ who reported that as the $\mathrm{N}$ rates increased so did plant height of onion.

Disregarding the effect of $\mathrm{N}$ rates, significantly longest onion plants were obtained from intra-row spacing of $15 \mathrm{~cm}$ and comparatively shortest plants were observed at intra-row spacing of $7.5 \mathrm{~cm}$ which was statistically at par with $10 \mathrm{~cm}$ intra-row spacing (Table 2). In agreement to the current finding, author [36] reported tallest onion plant from $10 \mathrm{~cm}$ intra-row spacing than plants grown at $7.5 \mathrm{~cm}$ and $5 \mathrm{~cm}$ at Aksum, northern Ethiopia. Auther [37] also found tallest plant at $25 \mathrm{~cm}$ intra-row spacing than at $15 \mathrm{~cm}$ intra-row spacing. The reduction in plant height at increased plant density might be attributed to the possible competition for soil moisture and nutrients as indicated by [38]. In contrast to the present study result, [39] recorded significantly different and highest plant height on radish at $15 \mathrm{~cm}$ and $10 \mathrm{~cm}$ spacing.

Table 2. Main effects of $N$ rates and intra-row spacing on days to maturity (days), plant height (cm) and leaf length (cm) of Qalafo onion variety grown at Gode under irrigated condition.

\begin{tabular}{llll}
\hline Treatments & $\begin{array}{l}\text { Days to maturity } \\
\text { (days) }\end{array}$ & $\begin{array}{l}\text { Plant height } \\
\text { (cm) }\end{array}$ & $\begin{array}{l}\text { Leaf length } \\
\text { (cm) }\end{array}$ \\
\hline $\mathrm{N}\left(\mathrm{kg} \mathrm{ha}^{-1}\right)$ & & & \\
0 & $101.75^{\mathrm{e}}$ & $47.83^{\mathrm{f}}$ & $42.19^{\mathrm{e}}$ \\
46 & $104.41^{\mathrm{d}}$ & $48.88^{\mathrm{e}}$ & $48.15^{\mathrm{d}}$ \\
69 & $105.33^{\mathrm{d}}$ & $49.93^{\mathrm{d}}$ & $52.63^{\mathrm{c}}$ \\
92 & $109.91^{\mathrm{c}}$ & $51.93^{\mathrm{c}}$ & $54.19^{\mathrm{bc}}$ \\
115 & $111.50^{\mathrm{b}}$ & $54.13^{\mathrm{b}}$ & $55.68^{\mathrm{ab}}$ \\
138 & $117.58^{\mathrm{a}}$ & $59.87^{\mathrm{a}}$ & $57.78^{\mathrm{a}}$ \\
$\mathrm{LSD}(5 \%)$ & 1.21 & 0.76 & 2.47 \\
$\mathrm{Spacing}(\mathrm{cm})$ & & & \\
7.5 & $106.28^{\mathrm{d}}$ & $51.23^{\mathrm{c}}$ & $50.16^{\mathrm{b}}$ \\
10 & $107.67^{\mathrm{c}}$ & $51.64^{\mathrm{bc}}$ & $51.06^{\mathrm{b}}$ \\
12.5 & $109.28^{\mathrm{b}}$ & $52.22^{\mathrm{b}}$ & $52.15^{\mathrm{ab}}$ \\
15 & $110.44^{\mathrm{a}}$ & $53.69^{\mathrm{a}}$ & $53.28^{\mathrm{a}}$ \\
LSD (5\%) & 0.99 & 0.62 & 2.02 \\
CV (\%) & 1.36 & 1.79 & 5.81 \\
\hline
\end{tabular}

$\mathrm{LSD}=$ least significant difference, $\mathrm{CV}=$ coefficient of variation in percent; Means within a column followed by the same letter are not significantly different at $\mathrm{P}<0.05$. 


\subsubsection{Leaf Length}

Irrespective of the intra-row spacing treatments, the longest leaf was obtained by application of $\mathrm{N}$ at the rate of $138 \mathrm{~kg} \mathrm{ha}^{-1}$ while the shortest plant leaf was observed in the control plots. The increased leaf length observed with the increased $\mathrm{N}$ fertilizer rates of 46, 69, 92, 115 and $138 \mathrm{~kg} \mathrm{~N}$ $\mathrm{ha}^{-1}$ was $14.13,24.75,28.44,31.97$ and $36.95 \%$, respectively, over the control (Table 2). This is because of $\mathrm{N}$ which is mainly concerned with the vegetative growth of plants through cell division and elongation $[33,26]$. The result is in line with the work of [27] who reported that a significant influence of leaf length was detected as the rate of $\mathrm{N}$ supply was increased from nil to $50 \mathrm{~kg} \mathrm{~N} \mathrm{ha}^{-1}$. Other author [40] also reported that as the $\mathrm{N}$ rates increased so did leaf length.

Without considering the effect of $\mathrm{N}$ rates, significantly longest leaf was obtained from Intra-row spacing of $15 \mathrm{~cm}$ and comparatively shortest leaf length was observed at intra-row spacing of $7.5 \mathrm{~cm}$ which was statistically at par with $10 \mathrm{~cm}$ intra-row spacing (Table 2). This result is in agreement to [36] finding, who reported that highest onion plant leaf length obtained from $10 \mathrm{~cm}$ intra-row spacing than at $7.5 \mathrm{~cm}$ and $5 \mathrm{~cm}$ intra-row spacing at Aksum northern Ethiopia. In agreement with this result, many authors reported that maximum leaf length of onion was recorded in plants spaced at a wider spacing $[41,42]$. These authors also reported that shortest leaves were observed in plants with the closet plant spacing of $10 \mathrm{~cm}$. The results showed that the wider spacing produced much longer leaves as compared to closer spacing, which might be due to relatively more nutrient and moisture availability and, hence, better growth of the plants.

\subsubsection{Leaf Number}

The leaf number of onion plant was significantly $(\mathrm{P}<0.01)$ affected by $\mathrm{N}$ fertilizer rates and intra-row spacing, and their interaction. The highest leaf numberwas obtained from the treatment combination of $138 \mathrm{~kg} \mathrm{~N}^{-1}$ and $15 \mathrm{~cm}$ intra-row spacing which is statistically at par with all the other inra-row spacing combined with $138 \mathrm{~kg} \mathrm{~N}^{-1}$ and $115 \mathrm{~kg} \mathrm{~N}$ $\mathrm{ha}^{-1}$ combined with $15 \mathrm{~cm}$ intra-row spacing respectively. The lowest leaf numberwas recorded from the plots supplied with nil $\mathrm{N}$ fertilizer at all intra-row spacing, which was also statistically at parity with $46 \mathrm{~kg} \mathrm{~N} \mathrm{ha}^{-1}$ combined with $7.5 \mathrm{~cm}$ intra-row spacing (Table 3). The increase in leaf number per plant at higher nitrogen and wider intra-row spacing could be attributed to the availability of enough growth factors that permit leaves to grow vigorously with less competition. This result is consistent with the findings of $[43,44]$ who confirmed that increased $\mathrm{N}$ level ranging from 100 to $200 \mathrm{~kg}$ $\mathrm{N} \mathrm{ha}^{-1}$ resulted in increased number of leaves per plant of onion.

The result of the current study is in agreement with the result of [45] who reported that the number of leaves produced per plant was increased in response to decreasing plant population density. Similarly, auther [41] found more number of leaves per plant of onion at minimum plant population density $\left(20\right.$ plants $\left.\mathrm{m}^{-2}\right)$ which decreased with increase in plant population. Auther [29] also reported that lower population density was best with regard to the number of leaves produced per plant.

Table 3. Interaction effect of $N$ fertilizer rates and intra-row spacing on leaf number per plant of Qalafo onion variety grown at Gode under irrigated condition.

\begin{tabular}{|c|c|c|c|c|c|c|}
\hline \multirow{2}{*}{ Intra- row spacing (cm) } & \multicolumn{6}{|c|}{$N\left(k h^{-1}\right)$} \\
\hline & $\mathbf{0}$ & 46 & 69 & 92 & 115 & 138 \\
\hline 7.5 & $7.31^{\mathrm{K}}$ & $7.52^{\mathrm{k}}$ & $10.16^{\text {hij }}$ & $10.50^{\text {hij }}$ & $11.60^{\mathrm{efg}}$ & $12.87^{\mathrm{abc}}$ \\
\hline 10 & $7.58^{\mathrm{k}}$ & $10.10^{\mathrm{ij}}$ & $9.73^{\mathrm{j}}$ & $12.16^{\text {cde }}$ & $11.63^{\mathrm{efg}}$ & $13.37^{\mathrm{ab}}$ \\
\hline 12.5 & $7.92^{\mathrm{k}}$ & $9.96^{\mathrm{ij}}$ & $11.06^{\mathrm{fgh}}$ & $11.83^{\mathrm{def}}$ & $12.66^{\mathrm{bcd}}$ & $12.84^{\mathrm{abc}}$ \\
\hline 15 & $7.97^{\mathrm{k}}$ & $9.86^{\mathrm{ij}}$ & $10.76^{\mathrm{hij}}$ & $12.03^{\text {cde }}$ & $12.82^{\mathrm{abc}}$ & $13.76^{\mathrm{a}}$ \\
\hline $\operatorname{LSD}(5 \%)$ & 0.96 & & & & & \\
\hline CV (\%) & 5.42 & & & & & \\
\hline
\end{tabular}

Means followed by the same letter are not significantly different at $\mathrm{P}<0.05, \mathrm{LSD}=$ least significant difference; $\mathrm{CV}=$ coefficient of variation in percent; $\mathrm{ns}=\mathrm{non}-$ significant at $\mathrm{p}<0.05$.

\section{Conclusion}

The field experiment was conducted to determine the effect of $\mathrm{N}$ fertilizer rates and intra-row spacing on onion growth. Results of the analysis revealed that the main effects of $\mathrm{N}$ rates and intra-row spacing showed a significant effect on days to maturity, plant height and leaf length. Besides, the interaction effect of $\mathrm{N}$ rates and intra-row spacing had significant effect on leaf number. Thus, according to this study, good growth performance of onion can be obtained from application of 138 $\mathrm{kg} \mathrm{N} \mathrm{ha}{ }^{-1}$ fertilizer combined with $15 \mathrm{~cm}$ intra-row spacing. However, this combination cannot be generalized for all onion cultivars and locations in areas under Shebelle river basin at
Gode district. Therefore, the experiment should be repeated over locations and seasons by including intra-row spacing narrower than $7.5 \mathrm{~cm}$ as well as $\mathrm{N}$ rates higher than $138 \mathrm{~kg} \mathrm{ha}^{-1}$.

\section{Acknowledgments}

The author extends a special gratitude to the Federal Democratic Republic of Ethiopia (FDRE), Ministry of Agriculture (MoA), Agricultural Technical Vocational Educational Training (ATVET) coordination office for the financial support for this study. In addition, the administrative office of Gode Polytechnic College is also appreciated for facilitating the finance allocated for this research and for their cooperation to use facilities of the College for this research work. 


\section{References}

[1] I. J. Golani, M. A. Vaddoria, D. R. Mehta, M. V. Naliyadhara and K. L. Dobariya., 2006. Analysis of Yield Components in Onion. Vegetable Research Station, Gujarat Agricultural University, Junagadh - 362 001, India, Indian J. Agric. Res., 40 (3): $224-227$.

[2] Hanelt P., 1990. "Taxonomy, Evolution, and History." In Onions and Allied Crops, edited by Haim D. Rabinowitch and James L. Brewster, 1-26. Boca Raton, Fla.: CRC Press.

[3] Corgan, J., M. Wall, C. Cramer, T. Sammis, B. Lewis and J. Schroeder, 2000. Bulb Onion Culture and Management. NMSU Agricultural Experiment Station Circular 563: 1-16.

[4] MoARD, 2009. Rural Capacity Building project. Course for Training of trainers on improved horticultural crop technologies. pp. 5-19.

[5] Grubben JH, Denton DA., 2004. Plant resources of tropical Africa. PROTA Foundation, Wageningen; Back huys, Leiden; CTA, Wageningen.

[6] Aklilu, S. 1997. Onion research and production in Ethiopia. Acta Horticulturae 433, 95-97.

[7] Lemma Dessalegn and E. Herath. 1994. Agronomic Studies on Allium. Pp.139-145. In: Horticultural Research and Development in Ethiopia. 1-3 December, 1992. Institute of Agricultural research and food and Agricultural Organization. Addis Ababa, Ethiopia.

[8] Lemma Desalegn and Shimeles Aklilu., 2003. Research experiences in onions production. Research report No. 55, EARO, Addis Ababa Ethiopia, P. 52.

[9] CSA (Central Statistics Agency), 2013. Area and production of major crops. Agricultural sample survey 2012/2013, private peasant holdings, Meher season, Statistical Bulletin 532, Addis Ababa.

[10] FAO (Food and Agricultural Organization), 2012.Crop production Accessed on. http:/www.faostat.fao.org, September $10,2012$.

[11] MARC (Melkasa Agricultural Research Center), 2004.Progress report for 1995 - 2003. EARO, Ethiopia.

[12] Upper Awash Agro-Industry Enterprise 2001. Progress Report 1996-2002, Addis Ababa, Ethiopia. Agricultural product 2001/2002, Addis Ababa, Ethiopia. Van Eeden F. J., Myburgh J., 1971. Irrigation trials with onions. Agroplantae3: 57-62.

[13] Gupta RP, Srivastava KJ, Pandey UB, Midmore DJ. 1994. Diseases and insect pests of onion in India. Acta Horticult. 358:265-372.

[14] Ethiopian Agricultural research Organization (EARO), 2004. Directory of released crop varieties and their recommended cultural practice, Addis Ababa, Ethiopia.

[15] SCF-UK DPPA (Save the children fund-United Kingdom and disaster prevention and preparedness Agency), 2003.Managing risks and opportunities on understanding of livelihoods of Somali regional state, Ethiopia.

[16] Wakley, A. and Black, C. A., 1934. Determination of organic matter in the soil by chromic acid digesion. Soil Sci., 63: 251-264.
[17] Dewis, J. and P, Freitas. 1975. Physical and chemical methods of soil and tissue analysis. FAO Bulletin No. 10. Rome. pp. 275.

[18] Olsen S. R. and L. A. Dean. 1965. Phosphorus. In: Methods of Soil Analysis. American Society of Agronomy. Madison, Wisconsin, 9: $920-926$.

[19] Cottenie, I., 1980. Soil and plant testing as a base for fertilizer recommendation. FAO soils bulletin No.38/2, FAO, and Rome Italy.

[20] Moodie, C., Smith, D. and McCreerry, R., 1954. Laboratory manual for soil fertility. Washngton State College, Monograph, 31-39.

[21] Hazelton, P.A. and Murphy, B. W, 2007 Interpreting soil test results $\left(2^{\text {nd }} \mathrm{ed}\right)$ : what do all the numbers mean?

[22] Donald A., Dan M., Jim S., John M, 2011. Soil testing interpretation guide. Oregon State University, U.S.A.

[23] Landon, J. R., 1991. Booker tropical soil manual: A handbook for soil survey and agricultural land evaluation in the tropics and sub-tropics. Longman Scientific and Technical, Essex, New York. 474p.

[24] Olsen, S. R., C. V. Cole, F. S. Watanable and L. A. Dean, 1954. Estimation of Phosphorus in soils by extraction with sodium bicarbonate. USDA, circular, 939:1-19.

[25] Brewster, J. L., 1994. Onions and other vegetable Alliums.CAB, International, Wallingford, UK. 236p.

[26] Marschner, H., 1995. Mineral nutrition of higher plants. $2^{\text {nd }} E d$. Academic Press, New York, P.674.

[27] Girma Z. 2011. Response of Onion (Allium Cepa L. Var. Cepa) To Organic and Inorganic Fertilizers at Gode, South-Eastern Ethiopia. Thesis submitted to the school of Graduate stdies Haramaya University.

[28] Khan, H., Iqbal, M., Ghaffoor, A. and Waseem, K., 2002. Effect of various plant spacing and different nitrogen levels on growth and yield of onion (Allium cepa L.). Online J. Biol. Sci., 2:545-547.

[29] Kumar, H., J. V. Singh, K. Ajay, S. Mahak, A. Kumar and M. Singh., 1998. Studies on the effect of spacing on growth and yield of onion (Allium cepa L.) cv Patna Red. Indian J. Agri. Res., 2: $134-138$.

[30] Islam, M. K., Alam, M. F., Islam, A. K. M. R., 2007. Growth and Yield Response of Onion (Allium Cepa L.) Genotypes to Different Levels of Fertilizers. Bangladesh Journal of Botany 36(1): 33-38.

[31] Hendrickson, P. and Swanson, M., 2003. Onion row spacing by seeding rate. NDSU, Crington research Extention Center.

[32] Brewster, J. L., 1990. Cultural systems and agronomic practices in temperate climates. pp. 2-30. In: Rabinowitch, H. D. and Brewster J. L. (Eds.). Onions and allied crops. Vol. 2. Agronomy, biotic interactions, pathology, and crop protection. CRC Press, Boca Raton, Florida, USA.

[33] Brady, N. C. 1985. The nature and properties of soils. $9^{\text {th }}$ Edition. New Delhi.

[34] Al-Fraihat, H. Ahmad, 2009. Effect of different nitrogen and sulphur fertilizer levels on growth, yield and quality of onion (Allium cepa L.). Jordan Journal of Agricultural Sciences, 5(2):155-165. 
[35] Mozumnder, S. N., Moniruzzaman, M., Halim, G. M. A. 2007. Effect of $\mathrm{N}, \mathrm{K}$ and $\mathrm{S}$ on the Yield and Storability of Transplanted Onion (Allium cepa L.) in the Hilly Region. Journal of Agriculture and Rural Development 5: 58-63.

[36] Kahsay Y. Fetien A. and Derbew B. 2013. Intra-row spacing effect on shelf life of onion varieties (Allium cepa L.) at Aksum, Northern Ethiopia. J. Plant breeding and crop Sci., 5(6): 127-136.

[37] Abubaker, S., 2008. Effect of plant density on flowering date, yield and quality attribute of Bush Beans (Phaseolus Vulgaris L.) under Center Pivot Irrigation System. Amer. J. Agri. and Biol. Sci., 3(4): 666-668.

[38] Karaye, A. K. and A. I. Yakubu, 2006. Influence of intra-row spacing and mulching on weed growth and bulb yield of garlic (Allium sativum L.) in Sokota, Nigeria. African Journal of Biotechnology., 5(3): 260-264.

[39] Perez MA, Ayub CM, Saleem BA, Virk NA, Mahmood N, 2004. Effect of Nitrogen Levels and Spacing on Growth and Yield of Radish (Raphanussativus L.). In Int. J. Agric. Biol. 6:3 publishing, UK.

[40] Muhammad, S. J., 2004. Studies on the management strategies for bulb and seed production of different cultivars of onions (Allium cepa L.). A dissertation submitted to Gomal University, Deraismil khan and Pakistan. 449p.
[41] Jilani M. S, Khan MQ, Rahman S., 2009. Planting densities effect on yield and yield components of onion (Allium cepa L.). J. Agric. Res. 47(4):397-404.

[42] Jilani, M. S., P. Ahmed, K. Waseem and M. Kiran, 2010. Effect of plant spacing on growth and yield of two varieties of onion (Allium cepa L.) Under the agro-climatic condition of D.I. Khan. Pakistan Journal of Science, 62: 37-41.

[43] Jilani M. S, and Ghaffoor A., 2004. Screening of Local Varieties of Onion for Bulb Formation. Int. J. Agric. Biol. 5(2):129-133. Pakistan.

[44] El-Tantawy, E. M. and A. K. El-Beik, 2009. Relationship between growth, yield and storability of onion (Allium cepa L.) with fertilization of nitrogen, sulphur and copper under calcareous Soil Conditions. Research Journal of Agriculture and Biological Sciences, 5(4): 361-371. http://www.insipub.com/rjabs/2009/361-371.pdf. Accessed June 2010.

[45] Tegbew. W. 2011. Yield and Yield Components of Onion (Alliumcepa var.cepa) Cultivarsas influenced by population density. Unpublished M.Sc. thesis submitted to the school of graduate studies of Haramaya University, Ethiopia. 